in that species. The greatest depth of body is contained $4 \frac{1}{2}$ times, the length of the head nearly $3 \frac{2}{3}$ times, and the breadth of the head almost 5 times in the total length. Liberia.

Balistes liberiensis exhibits a long, produced head; the profile of the head runs in a straight line to the muzzle. The length of the head is contained $3 \frac{1}{2}$ times and the greatest depth of body twice and one-fifth in the total length, and the eye $4 \frac{4}{5}$ times in that of the head. The body has large blue-black spots; the head is adorned with smaller bluish-green spots. 1st D. 3 ; 2nd D. 25 ; A. 27 ; P. 13. Liberia.-Anzeiger der K. Akad. der Wiss. in Wien, March 14, 1867, pp. 63-64.

\title{
On some points in the Anatomy of the Sipunculi.
} By S. Jourdain.

The researches of which I here give the most prominent results relate to the following species:- Sipunculus gigas, S. obscurus, S. vulgaris, and S. punctutissimus.

The integuments are destitute of those calcareous corpuscles, sometimes so curious in their form, which are met with in great quantities in the Holothuric. The spinules which roughen the anterior part of the body of $\boldsymbol{S}$. obscurus and $\boldsymbol{S}$. punctatissimus are dependent upon the epidermie envelope. Glandulæ exist in great numbers in the skin of S. obscurus, vulgaris, and punctatissimus, and cause it to appear finely punctate.

In $\boldsymbol{S}$. gigas the general cavity communicates with the exterior by an orifice furnished with a sphincter, situated at the posterior extremity of the body. Two branches springing from the fusiform ganglion, which terminates the nervous chain, surround this orifice with a nearly eomplete ring. A similar orifice is wanting in the three other species.

The ova or spermatozoids (for the sexes are not distinct) float in the liquid which fills the general cavity. In the last three species, they can issue only by a bilabiate pore placed upon the neck of the two cæca which open upon the sides of the dorsal region at the level of the anus. In $S$. gigas there is a pore similarly situated; but it is possible that the products of generation may be expelled by the posterior orifice, a sort of peritoneal canal in these Annulata. This well-ascertained arrangement seems to me to be of sufficient importance to justify the creation of a new generic group, to which I propose to give the name of Sipunculoporus ; this genus would at present include only a single species, Sipunculoporus gigas.

I shall now indicate an anatomical peculiarity which is perhaps connected with the presence of the posterior orifice-namely, the existence of tendinous fræna, or very slender threads, furnished with vibratile cilia, which connect the spiral convolutions of the digestive tube with the walls of the body, and seem to be intended to hold the former in their place.

The liquid of the general cavity contains two kinds of globules:(1) colourless discoid corpuscles, very like the globules of human 
blood, but of four times their diameter, and formed of a proteic substance, the ready alteration of which induces a rapid deformation of these corpuscles; (2) granular spherules furnished with singular processes, which, by interlacing, often agglomerate these bodies into masses of variable size : these bodies, which I propose to call villous globules, occur also in the cavitary liquid of many Invertebrata, and have been mistaken for portions of vibratile tissue. The vessel, forming a simple or double cæcum, which is attached to the first portion of the digestive tube and opens into the tentacular crown without furnishing ramifications to the integuments, contains discoid corpuscles very similar to those of the cavitary liquid, but of rather larger diameter. The corpuscles are set in motion by a ciliary epithelium, which likewise lines the interior of the tentacular crown. This tube, in my opinion, represents a very rudimentary circulatory system : whenever a portion of the nutritive fluid is vascularized, this vascularization is generally for the benefit of the function of respiration. The delicate structure of the tentacular membrane, and its relations to the vessel which I have just described, lead me to think that, as asserted by Dr. Williams, this region is the principal seat of hæmatosis. The thicker integuments, in contact only with the mud or muddy sand in which the Sipunculus lives enclosed, only play a secondary part, but, nevertheless, one which we cannot deny. The cavitary liquid, in fact, is subjected to a double movement of transport, perfectly recognized and described by $\mathbf{M}$. Quatrefages. This movement is caused by vibratile cilia distributed over the surface of the digestive.canal; and the fræna here and there bind together its convolutions : the inner wall of the tegumentary envelope is destitute of these appendages.

With regard to the cæcal tubes, in which certain anatomists have been inclined to recognize an organ of respiration, the following is the view which seems to be most plausible. They are formed essentially of a structureless membrane, strengthened by some smooth muscular fibres forming an irregular network, and by a layer of cells with brownish granular contents, such as occur in the gland destined, in many Invertebrata, to eliminate uric acid. The product of secretion, in the form of a clear greenish-brown liquid, often distends these cæca, which I regard as an organ of elimination analogous to the gland of Bojanus. These organs also serve for the emission of the ova and spermatozoids-a purpose which we also sometimes see fulfilled by the organ of Bojanus.

I was unable to make out with certainty where and how the ova and spermatozoids are formed. I did not succeed in detecting the generative organ, the development of which is perhaps temporary. I have, however, sometimes seen, on the terminal portion of the intestine, pedunculated vesicles, which might perhaps be very young ovigenous or spermatogenous cells. The question is still too obscure to allow me to hazard an assertion; and I propose to resume it by studying the nearly unknown embryology of these Gephyrea.Comptes Rendus, April 29, 1867, pp. 871-873. 


\section{$2 \mathrm{BHL}$ Biodiversity Heritage Library}

Jourdain, S. 1867. "On some points in the anatomy of the Sipunculi." The Annals and magazine of natural history; zoology, botany, and geology 19, 442-443.

View This Item Online: https://www.biodiversitylibrary.org/item/72153

Permalink: https://www.biodiversitylibrary.org/partpdf/61050

\section{Holding Institution}

University of Toronto - Gerstein Science Information Centre

\section{Sponsored by}

University of Toronto

\section{Copyright \& Reuse}

Copyright Status: NOT_IN_COPYRIGHT

This document was created from content at the Biodiversity Heritage Library, the world's largest open access digital library for biodiversity literature and archives. Visit BHL at https://www.biodiversitylibrary.org. 